\begin{tabular}{|l|l|}
\hline $\begin{array}{l}\text { 2. To: (Receiving Organization): } \\
\text { Distribution }\end{array}$ & $\begin{array}{l}\text { 3. From: (Originating Organization) } \\
\text { Technical Integration }\end{array}$ \\
\hline $\begin{array}{l}\text { 5. Proj./Prog./Dept./Div.: } \\
\text { SNE Project/W-441 }\end{array}$ & $\begin{array}{l}\text { 6. Design Authority/Design Agent/Cog. Engr.: } \\
\text { C. C. Pitkoff }\end{array}$ \\
\hline
\end{tabular}

8. Originator Remarks:

For approval and release.

11. Receiver Remarks:

11A. Design Baseline Document? $\bigcirc$ Yes

ONo \begin{tabular}{l} 
4. Related EDT No.: \\
NA \\
7. Purchase Order No.: \\
NA \\
9. Equip./Component No.: \\
NA \\
\hline 10. System/Bldg./Facility: \\
CVDF/ $142 \mathrm{~K}$ \\
\hline 12. Major Assm. Dwg. No.: \\
NA \\
\hline
\end{tabular}

13. Permit/Permit Application No.:

NA

14. Required Response Date:

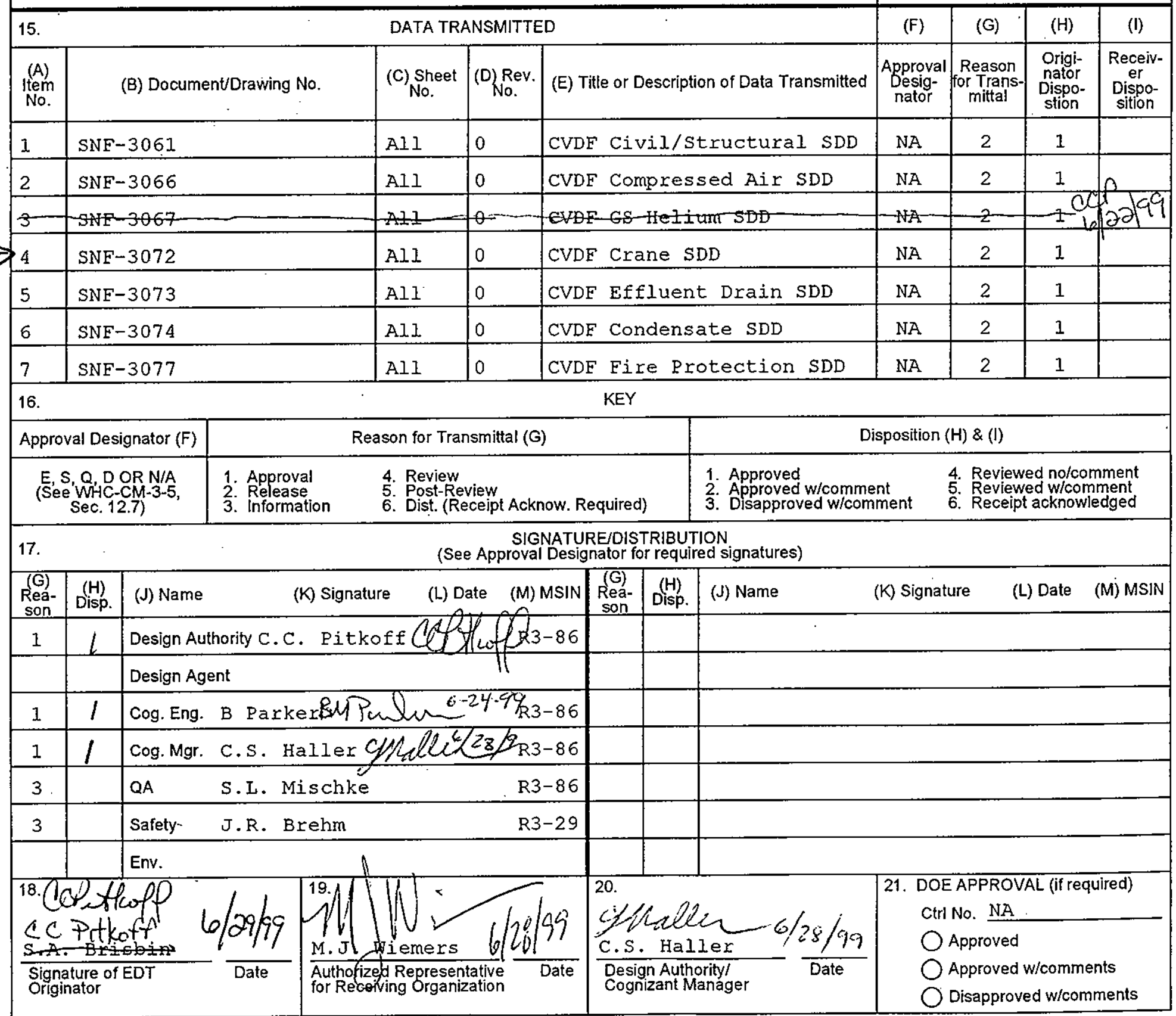




\section{Cold Vacuum Drying Facility Crane and Hoist System Design Description}

\section{C. Pitkoff}

DE\&S Hanford,

Richland, WA 99352

U.S. Department of Energy Contract DE-AC06-96RL13200

EDT/ECN: 626308

Org Code: $2 \mathrm{~F} 800$

B\&R Code: 39EW70400
UC: 510

CACN: 105568

COA: A000

Total Pages: 28

Key Words: SNF, CVD, W-441, design description, HOl, crane, hoist

Abstract: This document describes the Cold Vacuum Drying Facility (CVDF) crane and hoist system. The overhead crane and hoist system is located in the process bays of the CVDF. It supports the processes required to drain the water and dry the spent nuclear fuel contained in the multi-canister overpacks after they have been removed from the K-Basins. The cranes will also be used to assist maintenance activities within the bays, as required.

TRADEMARK DISCLAIMER. Reference herein to any specific commercial product, process, or service by trade name, trademark, manufacturer, or otherwise, does not necessarily constitute or imply its endorsement, recommendation, or favoring by the United States Government or any agency thereof or its contractors or subcontractors.

Printed in the United States of America. To obtain copies of this document, contact: Document Control Services, P.0. Box 950, Mailstop H6-08. Richland WA 99352, Phone (509) 372-2420; Fax (509) 376-4989.
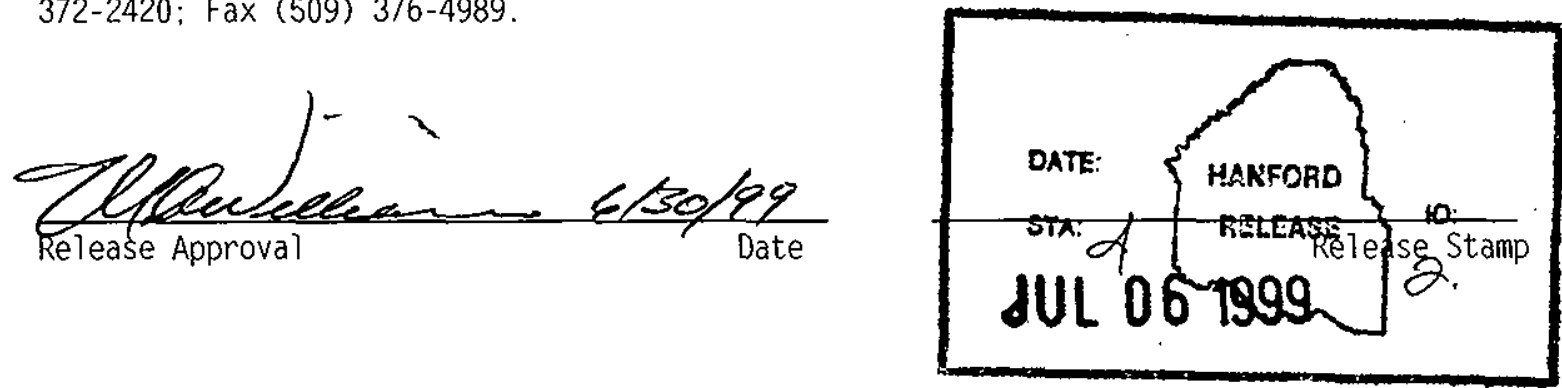

\section{Approved for Public Release}


SNF-3072

Revision 0

June 7, 1999

COLD VACUUM DRYING FACILITY

CRANE AND HOIST SYSTEM

DESIGN DESCRIPTION

SYSTEM 14 
SNF-3072

Revision 0

June 7, 1999

\section{TABLE OF CONTENTS}

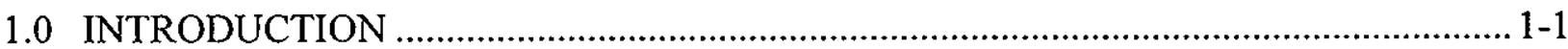

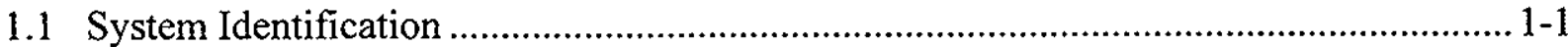

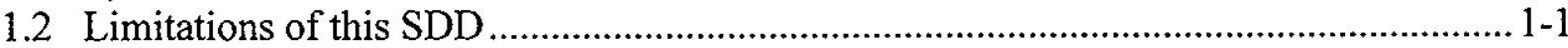

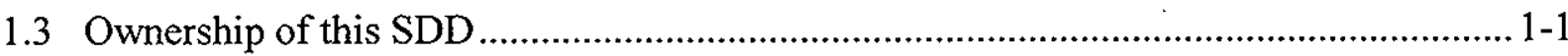

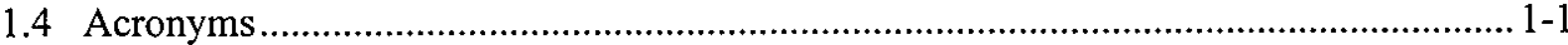

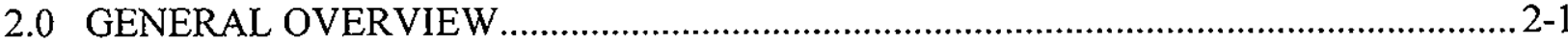

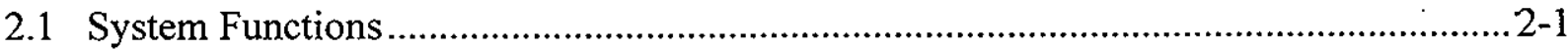

2.1.1 Normal Process Functions ……............................................................................ 2-1

2.1.2 Safety Functions.............................................................................................

2.2 System Classification........................................................................................... 2-1

2.3 Basic Operational Overview ....................................................................................... 2-1

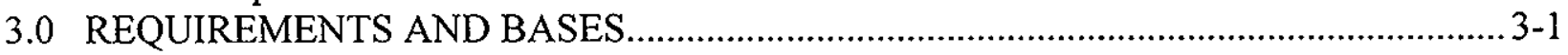

3.1 GENERAL REQUIREMENTS ............................................................................ $3-1$

3.1.1 System Functional Requirements .................................................................... 3-1

3.1.2 Subsystems and Major Components ..................................................................... 3-2

3.1.3 Boundaries and Interfaces .................................................................................. 3-4

3.1.4 Codes, Standards, and Regulations …………................................................... 3-4

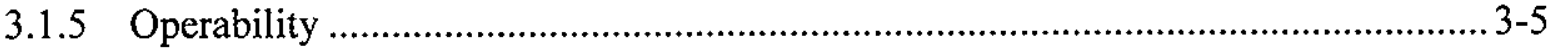

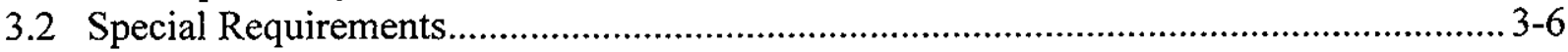

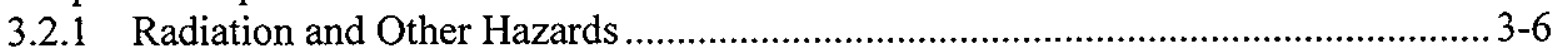

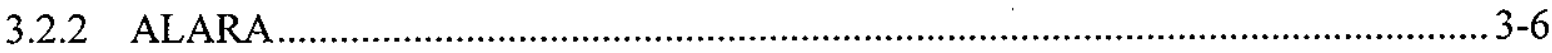

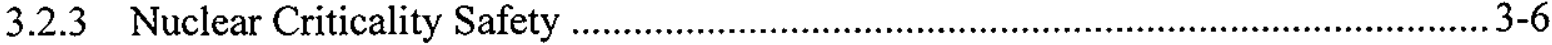

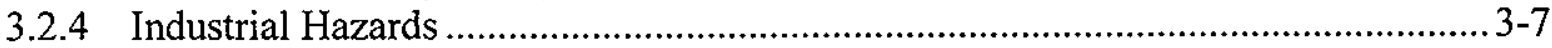

3.2.5 Operating Environment and Natural Phenomena ................................................ 3-7

3.2.6 Human Interface Requirements ......................................................................... 3-7

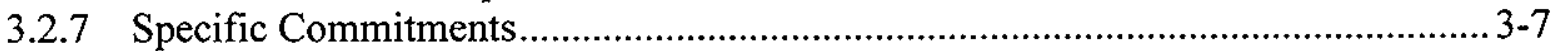

3.3 Engineering Disciplinary Requirements ................................................................... 3-8

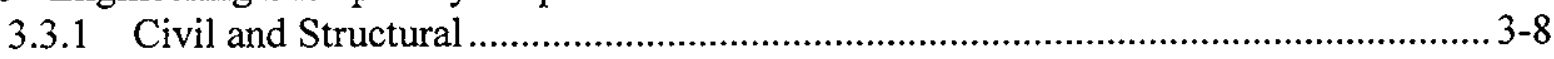

3.3.2 Mechanical and Materials ................................................................................... 3-8

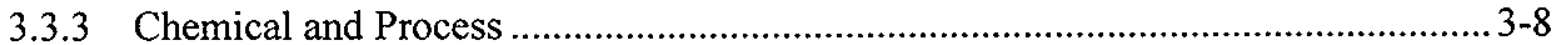

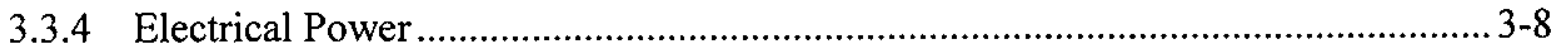

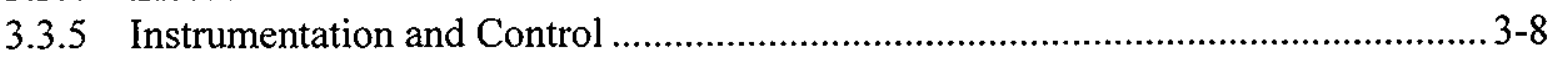

3.3.6 Computer Hardware and Software ..................................................................... 3-8

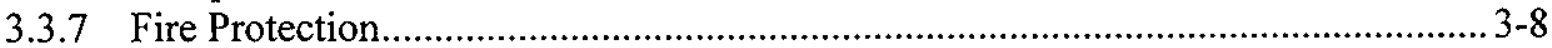

3.4 Testing And Maintenance Requirements.................................................................... 3-8

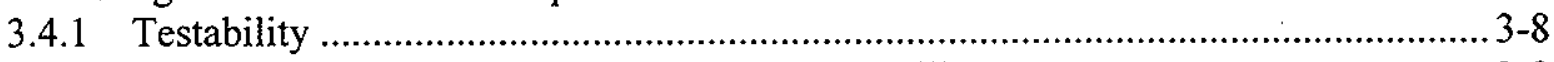

3.4.2 Technical Safety Requirement-Required Surveillances .......................................... 3-9

3.4.3 Non-Technical Safety Requirement Inspections and Testing................................. 3-9

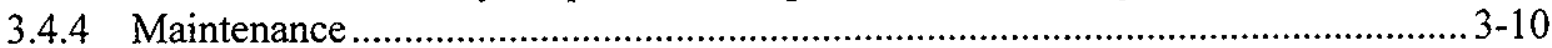

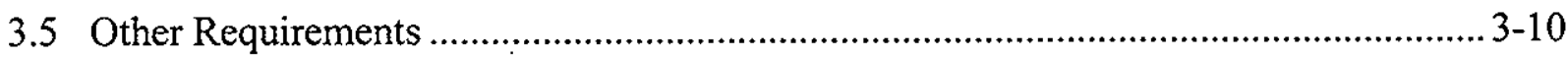

3.5.1 Security and Special Nuclear Material Protection ................................................. 3-10

3.5.2 Special Installation Requirements................................................................. 3-10

3.5.3 Reliability, Availability, and Preferred Failure Modes.......................................... 3-10 
SNF-3072

Revision 0

June 7, 1999

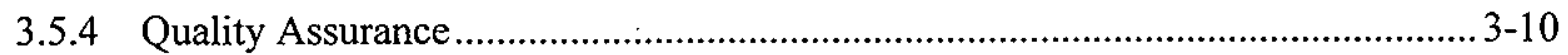

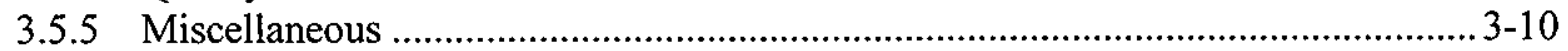

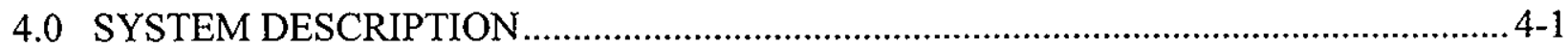

4.1 Configuration ..............................................................................................................

4.1.1 Description of System, Subsystems, and Major Components ................................ 4-1

4.1.2 Boundaries and Interfaces............................................................................ 4-2

4.1.3 Physical Location and Layout.............................................................................

4.1.4 Principles of Operation ................................................................................... 4-2

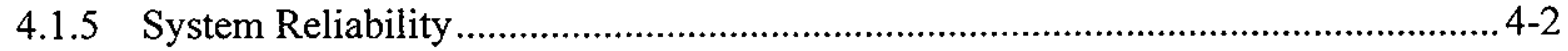

4.1.6 System Control Features ............................................................................. 4-2

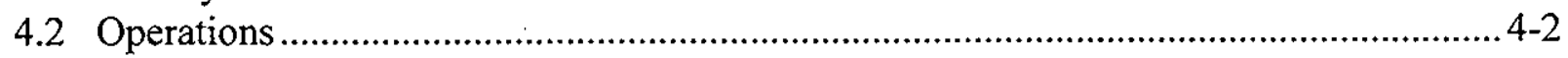

4.2.1 Initial Configurations (Pre-startup) ..................................................................... 4-2

4.2.2 System Startup .............................................................................................. 4-2

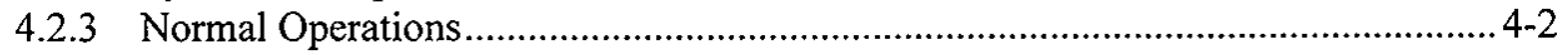

4.2.4 Off-Normal Operations .................................................................................. 4-3

4.2.5 System Shutdown ................................................................................................. 4-3

4.2.6 Safety Management Programs and Administrative Controls................................... 4-3

4.3 Testing And Maintenance ......................................................................................... 4-3

4.3.1 Temporary Configurations.................................................................................. 4-3

4.3.2 Technical Safety Requirement-Required ............................................................... 4-3

4.3.3 Non-Technical Safety Requirement Inspections and Testing.................................. 4-3

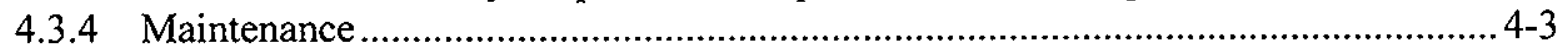


SNF-3072

Revision 0

June 7, 1999

\section{LIST OF FIGURES}

Figure 1-1. Location of Crane and Hoist System in the Process Bay.................................... 1-2

Figure 2-1. Cold Vacuum Drying Facility Cranes and Hoists...................................................2-2 
SNF-3072

Revision 0

June 7, 1999

\subsection{INTRODUCTION}

\subsection{System Identification}

This system design description (SDD) is for the Cold Vacuum Drying Facility (CVDF) overhead crane and hoist system. The overhead crane and hoist system, located in the process bays of the Cold Vacuum Drying Facility (CVDF), supports the processes required to drain the water and dry the spent nuclear fuel (SNF) contained in the multi-canister overpacks (MCOs) after they have been removed from the K-Basins. The location of the system in the process bay is shown in Figure 1-1.

\subsection{Limitations of this SDD}

This system design document is developed in accordance with the following documents and noted revisions: Safety Analysis Report, revision E; Safety Equipment List, revision 6; Design Requirements Document (DRD), revision 4, the Technical Safety Requirements, revision O-A, and associated engineering and design change notices to these documents and corresponding drawings.

\subsection{Ownership of this SDD}

The cold vacuum drying (CVD) Design Authority assigned to the crane and hoist system is responsible for the accuracy and technical content of this SDD. Any questions on the system or content of this document shall be resolved through the design authority.

\subsection{Acronyms}

$\begin{array}{ll}\text { ANSI/ANS } & \text { American National Standards/American Nuclear Society } \\ \text { ANSI/ASME } & \text { American National Standards/American Society of Mechanical Engineers } \\ \text { ASTM } & \text { American Society for Testing and Materials } \\ \text { CMAA } & \text { Crane Manufacturers Association of America } \\ \text { DBE } & \text { Design Basis Earthquake } \\ \text { DOE-RL } & \text { Department of Energy- Richland Operations Office } \\ \text { CVDF } & \text { Cold Vacuum Drying Facility } \\ \text { FSAR } & \text { Final Safety Analysis Report } \\ \text { IEC } & \text { International Electro-Technical Commission } \\ \text { NEMA } & \text { National Electric Manufacturers Association } \\ \text { NFPA } & \text { National Fire Protection Association } \\ \text { SCIC } & \text { Safety Class Instrument and Control } \\ \text { SDD } & \text { System Design Description } \\ \text { SNF } & \text { Spent Nuclear Fuel } \\ \text { SSC } & \text { Structure, System, and Component }\end{array}$




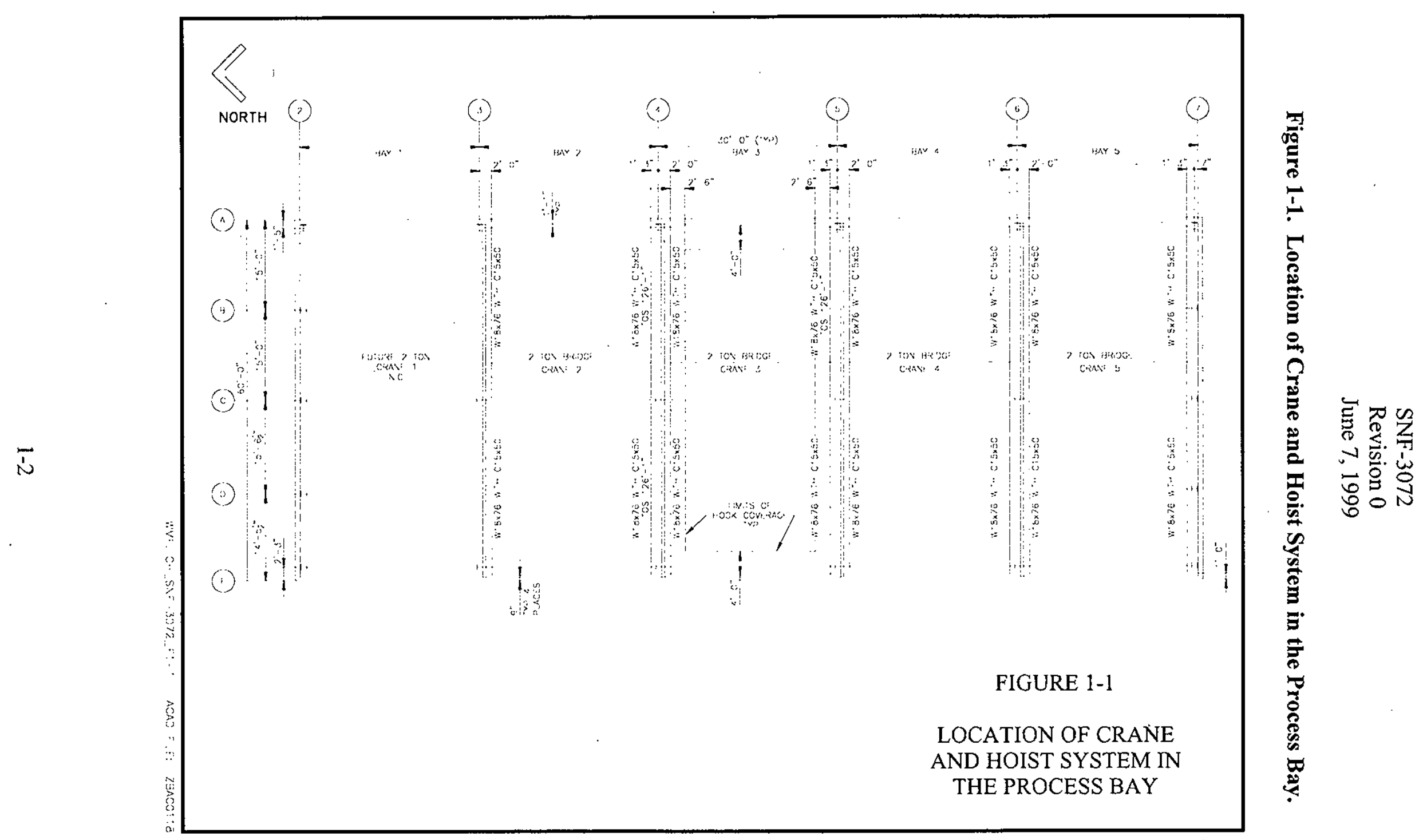


SNF-3072

Revision 0

June 7, 1999

\subsection{GENERAL OVERVIEW}

This section provides a general overview of the crane and hoist system. Section 2.1 describes the system functions and discusses the system's safety functions. Section 2.2 states the system classification and Section 2.3 outlines the basic operation of the system.

\subsection{System Functions}

\subsubsection{Normal Process Functions}

The function of the overhead cranes in the process bays of the CVDF is to provide the lifting capability to remove and replace the cask lid from the cask. The lid must be removed/replaced for installation/removal of the MCO ventilation/seal ring hood assembly used for removing the water from the MCO. They will also be used to assist in maintenance activities within the bays as required.

\subsubsection{Safety Functions}

The process bay cranes are designated as general service, but are seismically-qualified and considered in the 3:1 assessment within the bays. Safety considerations involve following critical lift procedures and required load testing.

\subsection{System Classification}

The process bay cranes are a subject of the CVDF FSAR (HNF-3553) and classified as general service. They are also classified by the U.S. Nuclear Regulatory Commission to be important to safety, category C.

\subsection{Basic Operational Overview}

Each process bay has an overhead bridge crane riding on a movable bridge girder. The bridge girder has end trucks that run on bridge rails that are fastened (welded connections) to the structural steel frame of the CVDF. Each crane has a capacity of 4,000 lbs. The bridge, trolley, and hoist are driven electrically and are capable of operation from the mezzanine level. See Figure 2-1. 
SNF-3072

Revision 0

June 7, 1999

Figure 2-1. Cold Vacuum Drying Facility Cranes and Hoists.

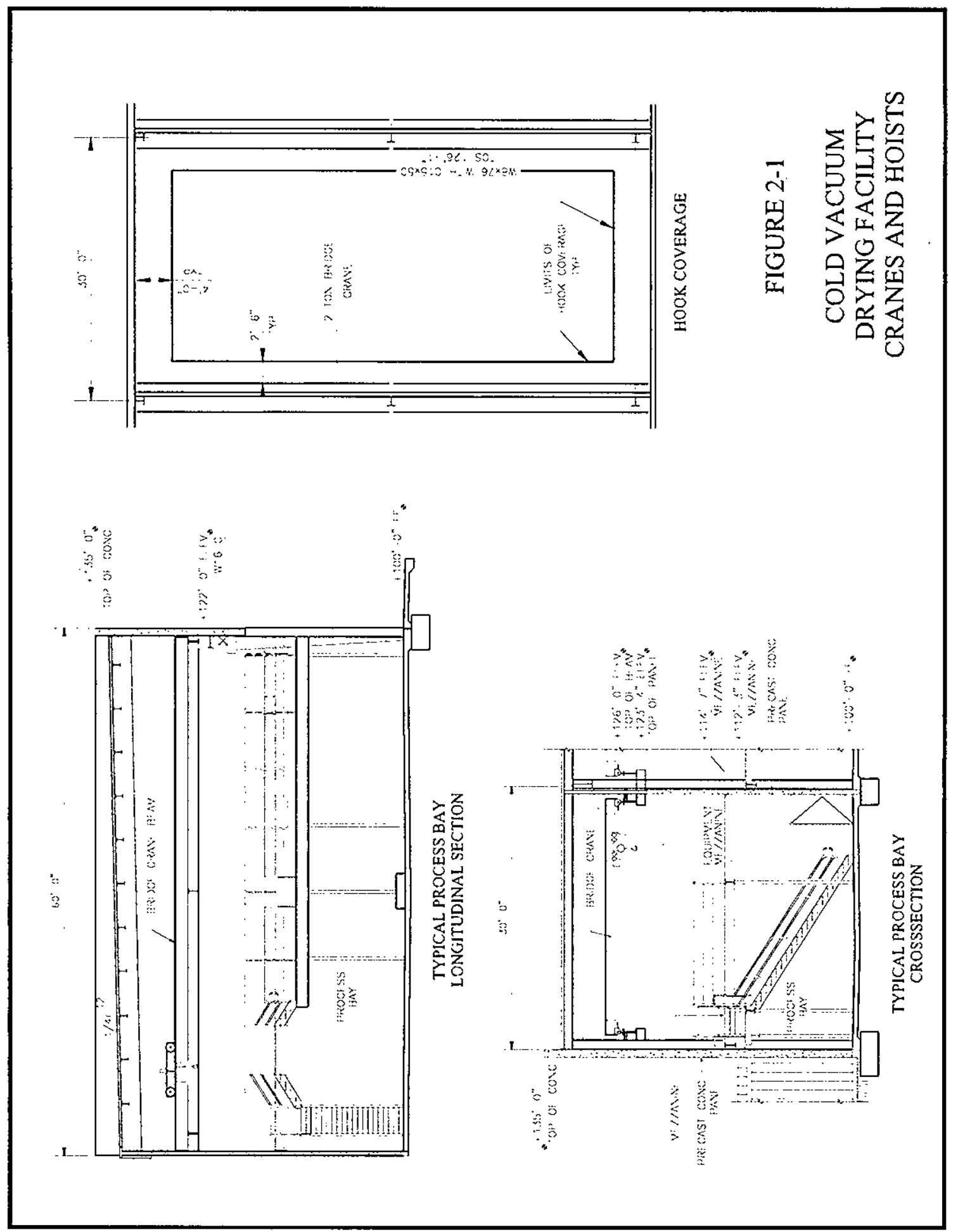

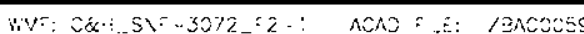


SNF-3072

Revision 0

June 7, 1999

\subsection{REQUIREMENTS AND BASES}

\subsection{GENERAL REQUIREMENTS}

\subsubsection{System Functional Requirements}

\subsubsection{Design Requirements}

1. Requirement: Each process bay shall be equipped with an overhead bridge crane with a service rating (hoisting capacity) of $4,000 \mathrm{lbs}$ (two tons).

Basis: HNF-SD-SNF-DRD-002, Rev. 4, Section 6.4.4.ww. Functions of the process bay bridge cranes are to remove and install the cask lid and the process hood onto the caskMCO. The cranes may also be used to assist in maintenance activities within the process bays as needed. The MCO transport trailer supports the cask-MCO during the vacuum drying process. The process does not require the capability to load or unload the cask$\mathrm{MCO}$ from the trailer at any time while it is inside the process bay. Therefore, a service rating of $4,000 \mathrm{lbs}$ was determined to be adequate for the process bay cranes.

How the system meets the requirement: This requirement is specified in the Construction Specification for the process bay crane system (W-441-C1) as a product specification for procurement of the crane system.

2. Requirement: The crane bridge, trolley, and hoist shall be driven by electric motors. Controls are permanently mounted to the mezzanine guardrail in each process bay.

Basis: HNF-SD-SNF-DRD-002, Rev. 4, Section 6.4.4.ww. Electric motors are the normal motive power sources for bridge cranes. The decision to mount crane controls at a fixed location on the mezzanine level was a design decision.

How the system meets the requirement: This requirement is specified in the Construction Specification for the process bay crane system (W-441-C1) as a product specification for procurement of the crane system.

\subsubsection{Safety Requirements}

3.1.1.2.1 Safety Class Requirements. There are no safety class requirements for the crane and hoist system.

3.1.1.2.2 Safety Significant Requirements. There are no safety significant requirements for the crane and hoist system.

3.1.1.2.3 Other Safety Requirements. There are no other safety requirements for the crane and hoist system. 
SNF-3072

Revision 0

June 7, 1999

3.1.1.3 Environmental Requirements. There are no environmental requirements for the crane and hoist system.

3.1.1.4 Mission-Critical Requirements. There are no mission-critical requirements for the crane and hoist system.

3.1.1.5 General Requirements. There are no unique general requirements for this system.

\subsubsection{Subsystems and Major Components}

The process bay bridge cranes consist of the following subsystems and major components: bridge girder, end trucks, bridge controls, bridge runway, runway electrification components, festooning system, wire rope hoist and trolley, push-button station, hook blocks, hooks, hoist rope, brakes, limit switches, and special tools. This section includes the requirements that characterize each of these components.

\section{Requirements:}

- Bridge Design: The process bay bridge cranes are an electric driven, top-running, single girder with capped channel design. They have a 4,000-lb hoisting capacity, and a Class D (heavy service) rating.

- Bridge Girder: The bridge girder conforms to the crane manufacturer's load design requirements and the applicable requirements of CMAA 74.

- $\quad$ End Trucks: End trucks are driven by dual motors, with a maximum tram speed of 50 $\mathrm{ft} / \mathrm{min}$, complete with brakes. Truck frames are constructed of welded steel channels and plates that form a rigid-box configuration. Seismic restraints are provided that prevent the end trucks from lifting off the runway rail during a seismic event.

- Bridge Controls: Bridge controls consist of IEC-rated contactors, 120-volt step-down transformer, thermal overload protection in all three phases, branch circuit motor fusing, and mainline contactor, all housed in a National Electrical Manufacturers Association (NEMA) 12 rated enclosure mounted on the bridge. The operator stops all motors without a time delay. All controls are capable of precise positioning of the bridge, trolley, and hoist. All movements are controllable to within $1 / 4$ in. from a complete standstill.

- Bridge Runway: The bridge runway is designed with a standard rail-over-runway beam configuration with end stops, sized as required to conform to load design requirements for the crane system.

- Runway Electrification: Runway electrification is an insulated system complete with all conductor bars, hangers, power taps, end caps, collector assemblies, and mounting 
SNF-3072

Revision 0

June 7, 1999

brackets, similar to the "SAF-T-BAR" series manufactured by Howell Corporation. Conductors are sized in accordance with NEC Articles 610, 620, 725, 760, and 800.

- Festooning Systems: Festooning systems are heavy-duty, flat cable systems similar to the "Duct-O-Wire" series flat cable electrification system manufactured by Duct-O-Wire Company. Festooning systems are provided complete with heavy duty track, end clamp and stop assemblies, trolley/saddle assemblies, cables, support brackets, junction boxes with terminal strips, and all accessories necessary for a complete installation.

- $\quad$ Electric Wire Rope Hoist and Trolley: The electric wire rope hoist and trolley have a two-ton capacity, and provide a minimum 27-ft lift at a minimum hoisting speed of 21 $\mathrm{ft} / \mathrm{min}$, with a geared upper and lower limit switch, and motor-driven trolley. The trolley is operable at a speed of $35 \mathrm{ft} / \mathrm{min}$. Inverter-controlled programmable speed controls are to be provided.

- Pushbutton Stations: Three three-motion, eight-button units, fully gasketed in enclosures with a NEMA rating of 12 comprise the pushbutton stations. Controls are permanently mounted to the mezzanine guardrail in each process bay. Controls are marked HOIST UP, HOIST DOWN, CARRIER FORWARD, CARRIER REVERSE, TROLLEY FORWARD, TROLLEY REVERSE, ON, and OFF. Controls are $115 \mathrm{~V}$.

- Hook Blocks: Hook blocks are constructed of rolled, forged steel and are entirely enclosed except for the rope openings. Lubrication fittings are recessed within the sheave pin or otherwise protected.

- Hooks: Hooks are forged steel or forged alloy steel and swivel freely when loaded. The main hook is the single type with a safety latch that is affixed without welding. Each hook is load tested at twice its rated capacity prior to shipping. After load testing, each hook undergoes magnetic particle inspection in accordance with ASTM A 275. Each hook also is also inspected to the requirements of MIL-I-8950B. Submittal of written certification of the test results is required.

- Hoist Rope: Wire rope is preformed, uncoated, improved plow steel, regular lay, with independent wire rope core. The rope has a breaking strength equivalent to the rated hoist capacity with a safety factor of five (5). A sufficient length of rope is provided to give at least two full wraps on the hoist drum when the hook is at its lowest position.

- Brakes: Brakes are designed, fabricated, and installed in accordance with CMAA 74. Brakes are adjustable from outside the equipment, and the motor is removable after dismantling or disabling the brake.

- Limit Switches: Adjustable control limit switches of an approved type, with automatic reset, are provided to prevent over-travel of the hoist in the raise direction only. Limit switches are the totally enclosed type that is operated by the hook block. Screw-type control limit switches are provided to prevent over-travel of the hoist when lowering. 
SNF-3072

Revision 0

June 7, 1999

Basis: All of the requirements in this section are included in the Construction Specification for the CVDF Project (W-441-C1). These requirements reflect guidance and constraints in imposed standards (particularly CMAA 74 and DOE-RL-92-36, Hanford Site Hoisting and Rigging Manual) relating to design, procurement, operation, and maintenance considerations for the crane system, together with supplemental discretionary detailing by the system design engineer to produce a suitably complete description for procurement, construction, and operation.

How the system meets the requirement: All of the requirements in this section were imposed (by inclusion in the Construction Specification for the CVDF Project) as product specifications on the procurement of the process bay cranes.

As a related topic, the DRD identifies requirements for design and procurement of the following special tools to assist crane operations in the process bays: Design descriptions and requirements for these tools are provided in a separate System Design Description (refer to SNF-3076).

- Cask Lid Lift Fixture. A lifting sling is provided for each bay to facilitate removal of the cask lid before the installation of the process hood and seal ring.

- Process Hood Lift Fixture. A separate sling is provided for each bay to facilitate the installation and removal of the process hood-seal ring to/from the cask.

\subsubsection{Boundaries and Interfaces}

In the CVDF Project Construction Specification (W-441-C1), the crane runway rails were designated to be part of the crane system (System 14), and the runway support beams were designated as part of the building structural steel (System 06-2). The support beams are shown on Drawing H-1-82132.

Electrical power distributed to panelboards in each of the process bays is $480-\mathrm{V}$, three-phase. power. Power from the panelboards to the process bay cranes is $120 \mathrm{~V}$, three (3)-phase power. The CVDF electrical system (System 20) is described in SNF-3075.

\subsubsection{Codes, Standards, and Regulations}

American Society for Testing and Materials (ASTM)

A 36-93a Standard Specification for Structural Steel

A307-93a Standard Specification for Carbon Steel Externally Threaded Fasteners

A325-93 Standard Specification for High-Strength Bolts for Structural Steel Joints

A123-89a Standard Specification for Zinc (Hot Galvanized) Coatings on Products

Fabricated from Rolled, Pressed, and Forged Steel Shapes, Plates, and Bars

Crane Manufacturing Association of America (CMAA) 
SNF-3072

Revision 0

June 7, 1999

CMAA 74, 1994, Specifications for Top Running and Under Running Single Girder Electric Overhead Traveling Cranes Utilizing Under Running Trolley Hoist, Crane Manufacturing Association of America, Charlotte, North Carolina.

National Fire Protection Association (NFPA)

NFPA-70 (1996), National Electrical Code (NEC)

American Society of Mechanical Engineers (ASME)

ANSI/ASME B30.16, 1993, Monorails and Underhung Cranes

DOE-RL-92-36 section 13.0, 1993, Hanford Site Hoisting and Rigging Manual, Overhead and Gantry Cranes, U.S. Department of Energy, Richland Operations Office.

WHC-SD-GN-DGS-30006 Rev 1, 1993, Seismic Design Guide for Safety Class 3 and 4 Equipment at the Hanford Site, Westinghouse Hanford Company, Richland, Washington.

\subsubsection{Operability}

The process bay cranes are designed to remain intact (even if they are rendered inoperable) during a design basis seismic, wind, or tornado event. During such an event, they are also designed not to damage safety-class equipment. Additional information on this topic is provided in Section 3.2.1.

1. Requirement: Process bay cranes are not permitted to move over the cask-MCO at any time during processing activities. This restriction applies to process bays in the Operation submode only.

Basis: This is a TSR control (TSR AC 5.14 -- Bridge Crane Movement Restrictions) imposed on the CVDF operation based on safety analysis considerations. The bridge crane movement restriction derives from analyses of MCO internal hydrogen explosion accident (SAR Section B3.4.2.4) and the thermal runaway reaction accident (SAR Section B3.4.2.5). Without controls, thermal runaway reactions and MCO overpressurization accidents have consequences that exceed onsite risk evaluation guidelines.

How the system meets the requirement: This constraint dictates that controls (either physical or administrative) must be established and maintained to ensure that movement of the crane is prevented from the time that draining operations begin until the proof-ofdryness demonstration is completed and the $\mathrm{MCO}$ isolation valves have been closed (except when such action is required as part of an approved recovery plan). Movement of the crane has the potential to damage key process lines (i.e., tempered water, ventilation air, and safety-class helium lines) attached to the process hood, leading to unacceptable 
SNF-3072

Revision 0

June 7, 1999

accident conditions. Restricting crane movement when the MCO is susceptible to internal hydrogen explosions and thermal runaway reactions reduces the likelihood of these events (SNF-2770, Chapter 6.0).

\subsection{Special Requirements}

\subsubsection{Radiation and Other Hazards}

Design basis accidents for the CVDF were evaluated in the SAR (HNF-3553, Rev. 0). Three of the accident scenarios considered (internal hydrogen explosion, external hydrogen explosion, and thermal runaway reaction) could feasibly be initiated by crane dropping a load (i.e., a cask lid or process hood) onto the cask-MCO, damaging the local ventilation air, tempered water, or safetyclass helium lines connected to it. The accident assessments in the SAR led to the imposition of a TSR control (TSR AC 5.14 -- Bridge Crane Movement Restrictions) on the operation. This requirement is reviewed in Section 3.1.5.

Because the lifts performed by these cranes (i.e., lifting and lowering cask lids and process hoods) have the capability for damage to the MCO, they are classified as NRC important-tosafety, based on the definition in 10 CFR 72.3 and as implemented in HNF-SD-SNF-DB-003. However, because any damage resulting from a cask lid drop has been determined to be very minor, the important-to-safety Category $\mathrm{C}$ classification has been assigned.

The process bay cranes are considered general service. However, the cranes are designed in accordance with natural phenomena and hazard performance category 3 criteria. Although they are general service, the cranes were seismically qualified and considered in the seismic 3-over-1 assessment of the process bays (HNF-4291). The crane support structures are anchored to meet the design basis performance category 3 seismic criteria. Engineering calculations demonstrating the adequacy of the CVDF process bay cranes to accomplish performance category 3 criteria and 3-over-1 protection of all safety-class and safety-significant SSCs are listed in SNF-3001.

\subsubsection{ALARA}

Positioning the crane controls on the mezzanine level enables the crane to be operated at a distance from the immediate area where potential significant radiation exposure could occur at the upper surface of the cask-MCO.

\subsubsection{Nuclear Criticality Safety}

Not applicable. 
SNF-3072

Revision 0

June 7, 1999

\subsubsection{Industrial Hazards}

Hazards and safety features related to worker safety were considered in the SAR (refer to HNF3553). The following provisions were identified to mitigate industrial hazards associated with the operation and improve worker safety:

- Cranes are operated by qualified personnel following established procedures.

- Cranes are designed with overlift protection.

- Crane maintenance are performed according to established procedures.

- All lifts by cranes passing over safety-class equipment are made in accordance with Department of Energy guidelines for critical lifts.

- Health physics personnel are present and provide surveillance of process bay operations, including crane operations.

- Radiological worker training include response procedures for evacuating the process bay in the event the continuous air monitor alarms.

These provisions may be imposed as requirements for CVDF process bay operations and maintenance, but do not constitute sources of new or unique requirements for the crane system design.

\subsubsection{Operating Environment and Natural Phenomena}

The cranes are designed to operate within the indoor environmental conditions described in Section 6.5 of HNF-SD-SNF-DRD-002, Rev 4. The cranes are designed in accordance with natural phenomena and hazard performance category 3 criteria, including seismic analysis criteria, and were seismically-qualified and considered in the seismic 3-over-1 assessment of the process bays (HNF-4291). The crane support structures are anchored for the design basis performance category 3 seismic criteria. The cranes have seismic restraints designed in to prevent the end trucks from lifting off the runway rails during a seismic event.

\subsubsection{Human Interface Requirements}

The cranes are designed consistent with the requirements in 29 CFR 1910.179 and DOE-RL-9236, Section 13.0.

\subsubsection{Specific Commitments}

Not applicable. 
SNF-3072

Revision 0

June 7, 1999

\subsection{Engineering Disciplinary Requirements}

\subsubsection{Civil and Structural}

Process bay crane and hoist loads are considered as live loads, in conjunction with other live loads, in the design of the process bay structure. Live-load criteria for the CVDF are given in GC-LOAD-01. This requirement is addressed elsewhere (SNF-3061).

The crane support structure is designed to provide seismic 3-over-1 protection for adjacent safety-class and safety-significant SSCs per WHC-SD-GN-DGS-30006, Rev. 2. Requirements for structural components of the process bay cranes (e.g., bridge, rails, end trucks) are discussed in Section 3.1.2 of this SDD.

\subsubsection{Mechanical and Materials}

Mechanical and materials requirements for the process bay crane system are discussed in Section 3.1.2.

\subsubsection{Chemical and Process}

There are no chemical and process requirements for this system.

\subsubsection{Electrical Power}

Electrical power requirements for the process bay crane system are discussed under Sections 3.1.2 and 3.1.3.

\subsubsection{Instrumentation and Control}

Requirements pertaining to the control system for the process bay cranes are discussed in Section 3.1.2.

\subsubsection{Computer Hardware and Software}

There are no computer requirements for this system.

\subsubsection{Fire Protection}

There are no fire protection requirements for this system.

\subsection{Testing And Maintenance Requirements}

\subsubsection{Testability}

There are no unique testability requirements for this system. 
SNF-3072

Revision 0

June 7, 1999

\subsubsection{Technical Safety Requirement-Required Surveillances}

There are no technical safety requirements for this system.

\subsubsection{Non-Technical Safety Requirement Inspections and Testing}

\section{Requirement:}

- Load Testing: The complete crane assembly is tested with 125 percent of the rated load on the main hook. This load is raised, lowered, held in any position, and transported at full speed, or as directed. The trolley and bridge are traveled while supporting this load over the full length of their respective runways.

- Control Test: Tests are conducted to verify that all applicable requirements for bridge controls have been met by the crane manufacturer and that operability of the control systems conforms to the specifications.

Basis: All lifts involving cask-MCO equipment are classified as critical lifts. These requirements are imposed in the SAR to provide the necessary assurances that the equipment (specifically the hoists) is appropriately qualified to perform critical lifts.

How the system meets the requirement: This requirement appears in the SAR. Load testing requirements for specific hoist components have been discussed in Section 3.1.2. Load testing requirements are imposed on the procurement of the crane system in the Project Construction Specification (W-441-C1).

2. Requirement: One or more turnover packages are prepared for process bay cranes and hoists (CVDF System 14). Crane load and control test reports are included in this package.

Basis: HNF-SD-SNF-DRD-002, Rev. 4, Section 7.6.1. This is a DRD requirement. The purpose of the requirement is to assure that all requred deliverables regarding test documentation for the cranes has been received by the CVDF operations component when the facility assumes ownership of the system.

How the system meets the requirement: Load tests results are identified both as submittals and as products in the Project Construction Specification (W-441-C1). 
SNF-3072

Revision 0

June 7, 1999

\subsubsection{Maintenance}

Maintenance is performed per DOE-RL-92-36 and the crane manufacturer's recommended maintenance schedule.

\subsection{Other Requirements}

\subsubsection{Security and Special Nuclear Material Protection}

Not applicable.

\subsubsection{Special Installation Requirements}

Not applicable.

\subsubsection{Reliability, Availability, and Preferred Failure Modes}

A Class D (heavy service) rating has been specified for the crane system. This rating serves to communicate to the system design engineer and the crane manufacturer that a relatively high degree of ruggedness and reliability are expected relative to the system's intended service and hoisting capacity and it invokes additional requirements in CMAA 74 for design and procurement of the system.

Potential failure modes in response to a design basis earthquake were considered in the seismic assessment of the process bays (HNF-4291). Additional information relating to this assessment is provided in Section 3.2.1.

\subsubsection{Quality Assurance}

The cranes meet the quality assurance requirements of 10 CFR 830.120 .

\subsubsection{Miscellaneous}

Not applicable. 
SNF-3072

Revision 0

June 7, 1999

\subsection{SYSTEM DESCRIPTION}

\subsection{Configuration}

\subsubsection{Description of System, Subsystems, and Major Components}

Each process bay is equipped with an electrically driven, top running, single-girder two-ton capacity bridge crane consisting of the following components:

- A bridge girder with rigid box-constructed end trucks. The end trucks are dual motor driven with a transverse speed of 50 feet per minute. They are equipped with electric brakes and removable seismic stops, which prevent the end trucks from lifting off the runway rail during a DBE.

- Bridge controls with International Electro-Technical Commission (IEC)-rated contactors, 120-volt step-down transformer, thermal overload protection, branch motor fusing, and mainline contactor. The controls are mounted in a National Electric Manufacturers Association (NEMA) 12-rated unit enclosure on the bridge. All bridge movements are controllable to within $1 / 4$ inch from a complete standstill.

- Bridge runway consisting of standard rail mounted on a runway beam with end stops. The runway also includes insulated electrification consisting of conductor bars, hangers, power taps, and collector assemblies and mounting brackets.

- Festooning system with track, end clamps, and stop assemblies, cables, support brackets, and junction boxes with terminal strips.

- Electric motor-driven trolley with an inverter-controlled programmable speed control and maximum speed of 35 feet per minute. The trolley carries the hoist and hook assembly.

- Electric wire hoist with a 27-foot lift at 21 feet per minute with a geared upper and lower limit switch. The hoist rope is preformed, uncoated, improved plow steel, regular lay with Independent Wire Rope Core (IWRC) with a safety factor of 5 above the rated crane capacity.

- Hook of forged steel, single type with safety latch and swivel type connection to the hoist rope. Hook blocks are rolled forged steel and entirely enclosed except for the hook openings.

- The cranes are controlled with a NEMA 12-rated, three-motion, eight-button unit enclosure. The controls are marked HOIST UP, HOIST DOWN, CARRIER FORWARD, CARRIER REVERSE, TROLLEY FORWARD, TROLLEY REVERSE, ON, and OFF. All movements of the crane are controllable to within $1 / 4$ inch from a complete standstill. 
SNF-3072

Revision 0

June 7, 1999

\subsubsection{Boundaries and Interfaces}

The crane bridge girder rides on the standard rail bridge runway rail. The limit of hook coverage is 4 feet from either end wall and 2 feet 6 inches from either side wall and has a vertical range of 26 feet as measured from the process bay floor.

\subsubsection{Physical Location and Layout}

The cranes are located at a height of 26 feet (top of runway beam) in the process bays. Refer to $\mathrm{H}-1-82132$ for details about the layout and connections of the crane structural support members of the building structure.

\subsubsection{Principles of Operation}

Electrically driven hoist, trolley, and bridge controlled with a pendulum-mounted push button station accessible on the mezzanine level and ground floor level.

\subsubsection{System Reliability}

Not applicable.

\subsubsection{System Control Features}

The system can be controlled from the mezzanine level within the process bays at a push button station.

\subsection{Operations}

Test specifications will be developed to identify factory acceptance, construction acceptance, and pre-operational test procedures. Additional information relating to specifications and procedures will be added when available.

\subsubsection{Initial Configurations (Pre-startup)}

Not applicable.

\subsubsection{System Startup}

The system is operational by energizing the crane from the applicable CVDF electrical distribution panel located in each bay and using the push button control pendulum to operate the crane. A detailed test specification will be developed to identify all prerequisite tests and alignments to support system startup.

\subsubsection{Normal Operations}

The crane is used to lift the cask lid and place it on the laydown area. It will also moves the 
SNF-3072

Revision 0

June 7, 1999

hood connection on the cask/MCO. Operating procedures will be developed to provide specific requirements.

\subsubsection{Off-Normal Operations}

The system will not operate on loss of power.

\subsubsection{System Shutdown}

The system is shut down when power is no longer available.

\subsubsection{Safety Management Programs and Administrative Controls}

The safety management programs and administrative controls for this SDD will be integrated into the SNF Project Integrated Safety Management System.

\subsection{Testing And Maintenance}

\subsubsection{Temporary Configurations}

Not applicable.

\subsubsection{Technical Safety Requirement-Required}

Not applicable.

\subsubsection{Non-Technical Safety Requirement Inspections and Testing}

The crane is tested with $125 \%$ of rated load on the main hook. The load test is considered a critical lift and procedures are written with detailed instructions per DOE-RL-92-36. After load testing, each hook is inspected nondestructively by magnetic particle according to ASTM A 275. The hooks are also inspected to the requirements of MLL-I-8950B after the testing.

\subsubsection{Maintenance}

Due to the short operating lifetime of the CVDF, no specific crane maintenance is expected other than that required by the crane manufacturer's recommended maintenance schedule. All maintenance is to be carried out in accordance with DOE-RL-92-36, Section 13.9 
SNF-3072

Revision 0

June 7, 1999

Appendix A

Source Documents 
SNF-3072

Revision 0

June 7, 1999

CMAA 74, 1994, Specifications for Top Running and Under Running Single Girder Electric Overhead Traveling Cranes Utilizing Under Running Trolley Hoist, Crane Manufacturing Association of America, Charlotte, North Carolina.

GC-LOAD-01, Standard Architectural-Civil Design Criteria, Design Loads for Facilities, ICF Kaiser Hanford Company, Richland, Washington.

HNF-3553, Rev. 0, 1999, Final Safety Analysis Report for the Cold Vacuum Drying Facility (draft), Fluor Daniel Hanford, Inc., Richland, Washington.

HNF-4291, 1999, Seismic Adequacy Review of Non-Safety Class (PC-0,1,2) Systems, Components, and Equipment that are Potential Seismic Interaction Hazards with Safety Class (PC3) Equipment at the CVD Facility, Numatec Hanford Corporation, Richland, Washington.

HNF-SD-SNF-DB-003, 1997, Spent Nuclear Fuel Project Path Forward, Additional NRC Requirements, Rev. 3, Westinghouse Hanford Company, Richland, Washington.

SNF-2770, 1998, Cold Vacuum Drying Facility Design Basis Accident Analysis Documentation, Rev. 0, Fluor Daniel Hanford, Inc., Richland, Washington.

SNF-3001, 1998, Cold Vacuum Drying Facility Supporting Data and Calculation Database, Fluor Daniel Hanford, Inc., Richland, Washington.

SNF-3061, 1999, Cold Vacuum Drying Facility, Civil/Structural System - System Design Description, COGEMA Engineering Corporation, Richland, Washington.

SNF-3075, 1999, Cold Vacuum Drying Facility, Electrical System - System Design Description, COGEMA Engineering Corporation, Richland, Washington.

SNF-3076, 1999, Cold Vacuum Drying Facility, Specialty Equipment and Special Tools - System Design Description, COGEMA Engineering Corporation, Richland, Washington.

W-441-C1, Rev 1, Construction Specification for Project W-441, Cold Vacuum Drying Facility, Merrick and Company,

WHC-SD-GN-DGS-30006, Rev 2, Guidelines for Assessing the Seismic Adequacy of Existing Performance Category Equipment at the Hanford Site, Fluor Daniel Hanford, Inc., Richland, Washington. 
SNF-3072

Revision 0

June 7, 1999

Appendix B

System Drawings

B-1 
SNF-3072

Revision 0

June 7, 1999

H-1-82132, Sht. 1, Structural Crane Plan, Sections, Details. 
SNF-3072

Revision 0

June 7, 1999

Appendix C

System Procedures

C-1 
SNF-3072

Revision 0

June 7, 1999

Operating procedures will be developed in the future. 


\section{DISTRIBUTION SHEET}

\begin{tabular}{|c|c|c|c|c|c|}
\hline \multirow{2}{*}{$\begin{array}{l}\text { To } \\
\text { Distribution }\end{array}$} & \multirow{2}{*}{\multicolumn{3}{|c|}{$\begin{array}{l}\text { From } \\
\text { Technical Integration }\end{array}$}} & \multicolumn{2}{|l|}{ Page 1 of 1} \\
\hline & & & & \multicolumn{2}{|c|}{ Date June 14, 1999} \\
\hline \multicolumn{4}{|c|}{ Project Title/Work Order/por 626313} & \multicolumn{2}{|c|}{ EDT No. $626308,1.763$} \\
\hline \multicolumn{4}{|c|}{$\begin{array}{l}\text { SNF-3061, SNF-3066(SNF-3067) SNF-3072, SNF-3073, SNF-3074, } \\
\text { SNF-3077(:SNF-3078, SNF-3079, SNF-3080, SNF-3081) on EDT.626311 }\end{array}$} & \multicolumn{2}{|l|}{ ECN No. NA } \\
\hline Name & MSIN & $\begin{array}{c}\text { Text } \\
\text { With All } \\
\text { Attach. }\end{array}$ & Text Only & $\begin{array}{c}\text { Attach./ } \\
\text { Appendix } \\
\text { Only }\end{array}$ & $\begin{array}{l}\text { EDT/ECN } \\
\text { Only }\end{array}$ \\
\hline W. C. Alaconis & $\mathrm{R} 3-86$ & $\mathrm{X}$ & & & \\
\hline L. L. Blehm & $\mathrm{X} 3-86$ & $X$ & & & \\
\hline K. A. Boes & R3-86 & $\mathrm{X}$ & & & \\
\hline J. R. Brehm & R3-86 & $\mathrm{X}$ & & & \\
\hline C. S. Haller & R3-11 & $X$ & & & \\
\hline L. C. McKenzie & $S 2-45$ & $\mathrm{X}$ & & & \\
\hline S. L. Mischke & R3-86 & $X$ & & & \\
\hline C. C. Pitkoff & R3-86 & $X$ & & & \\
\hline CVD Project File & R3-86 & $X$ & & & \\
\hline SNF Project File & R3-11 & $\mathrm{X}$ & & & \\
\hline
\end{tabular}

